\title{
MISKONSEPSI SIFAT KEASAMAN LARUTAN GARAM PARA GURU KIMIA DAN REKONSTRUKSI KONSEPTUALNYA
}

\author{
Sutrisno $^{1}$, M. Muchson ${ }^{2}$, Hayuni Retno Widarti ${ }^{3}$, Oktavia Sulistina $^{4}$ \\ 1,2,3,4 Jurusan Kimia Universitas Negeri Malang
}

\begin{abstract}
Abstrak - Telah terjadi miskonsepi untuk konsep hidrolisis atau konsep sifat keasaman larutan garam pada sebagian besar guru kimia di sekolah menengah, baik SMA maupun SMK di Jawa Timur. Dari sejumlah 49 orang guru, hanya 10 orang (20\%) guru yang mampu dengan baik dan benar menjelaskan sifat keasaman larutan garam $\left(\mathrm{NaCl}, \mathrm{KBr}, \mathrm{NH}_{4} \mathrm{Cl}\right.$, dan $\left.\mathrm{HCOOK}\right)$. Sebagai langkah memperbaiki konsep hidrolisis dan untuk mencegah terjadinya miskonsepsi yang dialami dilakukan melalui rekonstruksi miskonsepsi (konsep-salah). Setelah memperoleh rekonstruksi konsep ini, menyadari bahwa Pengetahuan/ Ilmu Kimia merupakan ilmu yang sistematik, menarik, mudah untuk dipelajari dan dibelajarkan. Sebanyak 95\% menyatakan ya/yakin, dan yang menyatakan biasa saja/ ragu, dan tidak yakin masing-masing 2,5\%. Demikian juga, setelah memperoleh kegiatan rekonstruksi konsep ini, peserta (para guru) sadar bahwa terjadi miskonsepsi pada dirinya.
\end{abstract}

Kata kunci: keasaman larutan garam, miskonsepsi, rekonstruksi konseptual

\begin{abstract}
There have been misconceptions for the concept of hydrolysis or the concept of acidity of salt solutions in most chemistry teachers in secondary schools, both high school and vocational school in East Java. From a total of 49 teachers, only 10 people $(20 \%)$ were able to properly and correctly explain the acidity of salt solutions $(\mathrm{NaCl}, \mathrm{KBr}, \mathrm{NH} 4 \mathrm{Cl}$, and $\mathrm{HCOOK})$. As a step to improve the concept of hydrolysis and to prevent the occurrence of misconceptions experienced through conceptual reconstruction of hydrolisis misconceptions. After obtaining the reconstruction of this concept, realizing that chemistry is a systematic and interesting science, easy to studied and learned. Amounts of $95 \%$ stated yes or sure, and who stated moderate/doubtful, and were not sure each is $2.5 \%$. Likewise, after obtaining this conceptual reconstruction, the participants (the teachers) realized that there was a misconception in themselves.
\end{abstract}

Keywords: acidity of salt solution, misconception, conceptual reconstruction

\section{PENDAHULUAN}

Pemahaman konsep secara komprehensif bagi seorang guru adalah mutlak, sebab dari seorang gurulah, akan terjadi transfer ilmu-pengetahuan kepada siswanya. Pemahaman konsep yang kurang atau bahkan tidak komprehensif oleh guru akan menjadi bumerang bahkan malapetaka bagi siswa untuk memperoleh ilmu yang benar dan tepat. Pemahaman yang salah, rancu, atau (mungkin) miskonsepsi guru akan berdampak serius pada siswa, menyebabkan pemahaman konsep siswa yang tidak tepat bahkan salah. Dari sinilah akan terjadi kesalahan fatal atau kegagalan total untuk terjadinya transfer pengetahuan tersebut. Konsep merupakan sentralnya ilmu-pengetahuan -Concept is the Central of Science- (Enger \& Yager, 2009). Karenanya, kesalahan atau kegagalan penyampaian, transfer, atau penanaman konsep kepada siswa sebagai akibat miskonsepsi guru berdampak fatal bagi siswa dalam menguasai atau memahami konsep, dan lebih lanjut pada ilmu pengetahuannya. Meskipun kegagalan pemahaman konsep atau pemahaman konsep yang salah (tidak tepat) oleh siswa bukan satu-satunya sumber miskonsepsi. Namun tidak bisa dipungkiri bahwa miskonsepsi para siswa juga dapat berasal dari guru. Miskonspesi dapat terjadi karena prakonsep (preconcepts) dan miskonsepsi dari sekolah (school-made misconecptions) (Barke et al., 2009: 21). Miskonsepsi sebagai akibat prakonsep dibawa oleh peserta didik melalui pengamatan terhadap fenomena 
kesehariannya. Misalnya, "gas adalah zat yang tidak mempunyai massa" dan "pembakaran adalah sesuatu yang lepas ke udara". Jadi, miskonsepsi dapat terjadi karena konsep yang dikonstruksi sendiri oleh siswa, dan konsep yang dimilikinya BERBEDA dengan konsep yang dimiliki guru. Sedangkan, school-made misconceptions adalah miskonsepsi yang berkembang atau berasal dari pengajaran (pembelajaran) yang kurang-tepat atau salah berasal dari guru) dan/atau topik-topik yang sukar (difficult topics). Misalnya, pada topik kesetimbangan kimia ("konsentrasi reaktan sama dengan konsentrasi produk"), asam lemah ("mempunyai pH 3 atau di atas 3"), dan reaksi redoks ("selalu melibatkan oksigen").

Dalam konteks school-made misconceptions, penguasaan dan pemahaman konsep oleh guru (dan/atau dosen) secara komprehensif adalah mutlak untuk mengatasi atau mencegah miskonsepsi. Di samping pemahaman yang komprehensif dari seorang guru agar mampu berperan sebagai agent of changes maka harus mampu membelajarkan konsep atau topik secara benar dan tepat. Penguasan atau pemahaman konsep yang kurang/tidak komprehensif dari guru atau pembelajar "biasanya" akan berdampak pada kurang-tepatnya dalam pembelajaran atau "transfer konsep" kepada pebelajar. Apalagi, jika dibarengi dengan "sukarnya-konsep/topik" yang bisa dan sangat mungkin dialami oleh para guru. Oleh karena itu memahami karakteristik konsep dalam ilmu kimia akan membantu pemahaman yang benar terhadap konsep tersebut.

Berdasarkan karakteristik konsepnya, ilmu kimia dibangun oleh konsep yang sangat beragam, yakni konsep konkrit (seperti pembakaran, titik didih, titik lebur, dan reaksi kimia), konsep abstrak (seperti atom, molekul, ion, massa atom, dan massa molekul), dan konsep terdefinisi (seperti satu mol, teori asam dan basa, dan bilangan oksidasi). Karenanya, guru harus mampu memadukan ketiga karakter konsep tersebut secara utuh (jika di dalam suatu topik menagndung ketiga karakter konsep ini) dalam pembelajaran agar siswa dapat memahami suatu konsep dengan benar. Artinya, konsep yang dimiliki siswa sama dengan yang dimiliki guru, dan sama atau identik dengan yang dimiliki oleh kimiawan. Apabila terjadi ketidaksamaan diantara kedua atau ketiganya maka telah terjadi miskonsepsi pada siswa. Ketiga ranah konsep ini sejalan dengan ciri ilmu kimia yang mempelajari tentang sifat-sifat, perubahan dan energi yang menyertai perubahan, dan struktur suatu zat (Timberlake \& Timberlake, 2014). Sifat suatu zat dominan pada ranah konsep konkrit, perubahan dan energi yang menyertai perubahan dominan pada ranah konsep terdefinisi, dan struktur dominan di ranah konsep abstrak. Berdasarkan ketiga karakteristik konsep yang terdapat dalam ilmu kimia tersebut, maka objek yang dikaji dalam ilmu kimia adalah materi beserta karakteristik yang menyertainya.

Untuk mengatasi pola belajar seseorang, sebagai akibat dari karakteristik ilmu kimia, maka Johnstone, Gabel, dan lainnya mengusulkan tiga level berfikir (tiga tingkatan representasi) dalam mempelajari ilmu kimia: (1) makroskopik (macroscopic: nyata, tampak/terlihat, dan laboratorium), (2) molekuler atau submikroskopik (molecular or submicrosopics: atom, molekul, ion, struktur kimia), dan simbolik atau representasional (symbolic or representational: simbol, persamaan reaksi, formula, molaritas, tabel, grafik) (Johnstone, 1991 \& Gabel, 1999). Belajar ilmu kimia pada level makroskopik adalah dengan cara mengamati zat berdasarkan ciri-ciri fisiknya (yang bisa dilihat, diraba/disentuh, dan bau). Sedang pada level submikroskopik adalah menjelaskan proses yang terjadi pada zat tersebut pada tingkat partikel, dan yang dimaksud pada level simbol atau representasi adalah mengubah informasi tentang zat ke dalam bentuk simbol, persamaan, formula, tabel, atau grafik (Mahaffy, 2006). Tiga level berfikir dalam mempelajari ilmu kimia ini merupakan hubungan timbal-balik dan merupakan satu kesatuan yang utuh, sekaligus sebagai karakteristik dasar ilmu kimia (Barke et al., 2009: 21 \& Sirhan, 2007).

Disamping dua karakteristik tersebut (tiga level konsep dan tiga level berfikir), konsep-konsep dalam ilmu kimia bersifat hierarkial atau berjenjang (Sastrawijaya, 1988). Konsep demikian hanya dapat dipelajari dengan baik apabila seseorang telah memahami konsep lain yang mendasari konsep tersebut (Nakhleh, 1992). Contohnya, memahamin konsep reaksi redoks harus memahami secara komprehensif dan benar tentang konsep bilangan oksidasi, konsep persamaan reaksi akan dipahami dengan baik jika sudah menguasai konsep rumus kimia (chemical formula), dan konsep $\mathrm{pH}$ suatu larutan jika sudah menguasai dengan baik konsep asam dan basa menurut teori asam-basa Arrhenius. Dari pembahasan di atas, tidak bisa dipungkiri bahwa penguasaan konsep awal (prior-knowledge) atau prakonsep, penguasaan konsep dalam ilmu kimia yang benar dan utuh dan strategi pembelajaran yang tepat oleh guru (sebagai fasilitator belajar siswa) menjadi modal utama untuk mencegah atau setidaknya mengurangi miskonsepsi siswa dalam memahami ilmu kimia. 
Namun demikian, apa yang terjadi di lingkungan praktik pembelajaran kimia? Survey dan penjaringan penguasaan konsep kepada para guru kimia untuk menjelaskan atau mendeskripsikan sifat keasaman larutan garam (di Sekolah Menengah lebih lazim dengan topik HIDROLISIS). Penjaringan penguasaan atau pemahaman konsep ini melalui kuesioner terhadap para guru kimia yang terorganisir dalam MGMP (Musyawarah Guru Mata Pelajaran) Kimia Kabupaten Ponorogo (2016) dan Kabupaten Tuban (2017). Mayoritas para guru mengalami miskonsepsi dalam hal memberikan penjelasan mengapa larutan natrium klorida bersifat netral, larutan amonium klorida bersifat asam, dan larutan natrium asetat bersifat basa, yang terhadap ketiga larutan ini diuji dengan kertas lakmus biru dan merah. Hal yang identik, juga dialami oleh para mahasiswa kimia Jurusan Kimia FMIPA UM.

Berdasarkan hal-hal yang telah dideskripsikan di atas, dilakukan survey kepada para guru kimia di wilayah Provinsi Jawa Timur. Mengapa dilakukan kepada para guru? Dengan mempertimbangkan, bahwa miskonsepsi dapat berasal dari guru dan/atau konsep atau topik yang sukar (difficult concepts), maka penguasaan konsep yang benar dan baik (un-misconcepstions) dari para guru diyakini dapat mencegah atau menghindari terjadinya miskonsepsi para siswa. Jika terjadi miskonsepsi selanjutnya dilakukan pembenahan atau pembetulan melalui rekonstruksi konsep dari konsep yang mengalami miskonsepsi menggunakan pendekatan konflik kognitif dengan strategi inkuiri terbimbing atau inkuiri terstruktur.

\section{METODE}

\section{Rancangan Tindakan.}

Penelitian ini merupakan survey yang dilakukan terhadap guru-guru kimia SMA dan SMK di wilayah Kabupaten Malang. Penetapan sasaran atau subjek secara aacak, yakni kepada para guru yang telah diundang oleh MGMP Kimia SMA dan MGMP Kimia SMK Kabupaten Malang, dan hadir pada saat kegiatan ini dilakukan.

\section{Sasaran atau subjek.}

Survey penguasan atau pemahaman konsep dilakukan terhadap para guru kimia SMA dan guru SMK yang terwadahi dalam forum MGMP Kimia SMA dan MGMP Kimia SMK sebanyak 49 orang. Hasil penajringan ini selanjutnya dianalisis dan diidenifikasi untuk melihat terjadi atau tidak-terjadi miskonsepsi untuk topik Sifat Keasaman Larutan Garam (Konsep Hidrolisis).

\section{Waktu dan Tempat.}

Penjaringan dan kegiatan rekonstruksi dilakukan pada bulan Juli 2018 bertempat di SMA Negeri 1 Kepanjen dan SMA/SMK Muhammadiyah Kepanjen Kabupaten Malang.

\section{Instrumen penelitian.}

Instrumen yang digunakan dalam penelitian ini ada dua macam, yakni (1) kuesioner pemahaman konsep dan (2) angket tentang respon guru terhadap kegiatan rekonstruksi konsep hidrolisis. Kuesioner pemahaman konsep hidrolisis (sifat keasaman larutan garam) yang berisi tentang pertanyaan untuk dijawab oleh para guru. Adapun pertanyaan dalam kuesioner adalah sebagai berikut:

1. Untuk larutan-larutan berikut: $\mathrm{NaCl}$ (natrium klorida), $\mathrm{KBr}$ (kalium bromida), $\mathrm{NH}_{4} \mathrm{Cl}$ (amonium klorida), dan HCOOK (kalium format atau kalium metanoat), mempunyai $\mathrm{pH}$ sama dengan, lebih besar, atau lebih kecil dari 7 (tujuh)?

2. Dari jawaban soal di atas (No.1) yang Anda sampaikan, mengapa $\mathrm{pH}$ masing-masing seperti yang Anda sebutkan? Berikan penjelasan singkat!

Kuesioner ini disampaikan saat sebelum para guru menerima informasi apapun yang berkaitan dengan pemahaman konsep hidrolisis dan dikerjakan saat penjaringan berlangsung. Analisis dilakukan setelah selesai penjaringan dan secara simultan dilakukan rekonstruksi konsep. Kegiatan rekonstruksi konsep dilakukan terhadap keseluruhan responden, baik yang menjawab benar maupun yang menjawab kurang 
atau tidak benar. Sedangkan angket respon terhadap kegiatan rekonstruksi dilakukan setelah selesai kegiatan.

\section{Pengumpulan data}

Data dikumpulkan dengan langkah-langkah sebagai berikut: (1) penjaringan pemahaman konsep dengan instrumen pemahaman konsep, (2) analisis dan pemetaan hasil-hasil pemahaman konsep, (3) tindakan rekonstruksi konsep melalui ekspositori, demonstrasi, diskusi, tanya-jawab, dan umpan-balik (sebagai refleksi keberhasilan rekonstruksi), namun dengan jenis pertanyaan yang berbeda dari segi zat atau senyawanya, bukan konten konsepnya. dan (4) penjaringan respon guru terhadap kegiatan rekonstruksi. Pertanyaan refleksi adalah $\mathrm{NaBr}, \mathrm{CH}_{3} \mathrm{COONa}$, dan $\left(\mathrm{NH}_{4}\right)_{2} \mathrm{SO}_{4}$. Semua data kuantitatif diolah dengan teknik rerata.

\section{HASIL DAN PEMBAHASAN}

Hasil penjaringan penguasaan konsep sifat keasaman larutan garam trehadap 49 orang guru SMA dan SMA di Kabupaten Malang untuk Pertanyaan (1), hasilnya tercantum pada Tabel 1.

Tabel 1. Ragam jawaban nilai $\mathrm{pH}$ larutan $\mathrm{NaCl}, \mathrm{KBr}, \mathrm{NH}_{4} \mathrm{Cl}$, dan $\mathrm{HCOOK}(7 \leq \mathrm{pH} \leq 7)$

\begin{tabular}{|c|c|c|c|c|c|c|c|c|}
\hline \multirow{3}{*}{$\begin{array}{l}\text { Nilai } \mathrm{pH} \text { jawaban } \\
\text { responden }\end{array}$} & \multicolumn{8}{|c|}{ Jumlah jawaban responden dan persentasenya untuk larutan } \\
\hline & \multicolumn{2}{|c|}{$\mathrm{NaCl}$} & \multicolumn{2}{|c|}{$\mathbf{K B r}$} & \multicolumn{2}{|c|}{$\mathrm{NH}_{4} \mathrm{Cl}$} & \multicolumn{2}{|c|}{ HCOOK } \\
\hline & orang & $\%$ & orang & $\%$ & orang & $\%$ & orang & $\%$ \\
\hline $\mathrm{pH}=7$ & 45 & 92 & 42 & 80 & 2 & 8 & 0 & 0 \\
\hline $\mathrm{pH}<7$ & 0 & 0 & 3 & 12 & 43 & 88 & 1 & 4 \\
\hline $\mathrm{pH}>7$ & 0 & 0 & 0 & 0 & 0 & 0 & 44 & 90 \\
\hline Jawaban lain & 2 & 4 & 2 & 4 & 2 & 4 & 2 & 4 \\
\hline Tidak menjawab & 2 & 4 & 2 & 4 & 2 & 4 & 2 & 4 \\
\hline Jumlah & 49 & 100 & 49 & 100 & 49 & 100 & 49 & 100 \\
\hline
\end{tabular}

Konsep yang benar adalah sebagai berikut: (1) larutan $\mathrm{NaCl}$ dan $\mathrm{KBr}$ mempunyai $\mathrm{pH}=7$, (2) $\mathrm{pH}$ larutan $\mathrm{NH}_{4} \mathrm{Cl}<7$, dan (3) $\mathrm{pH}$ larutan HCOOK $>7$. Cuplikan jawaban responden untuk pertanyaan ini seperti tampak pada Gambar 1.

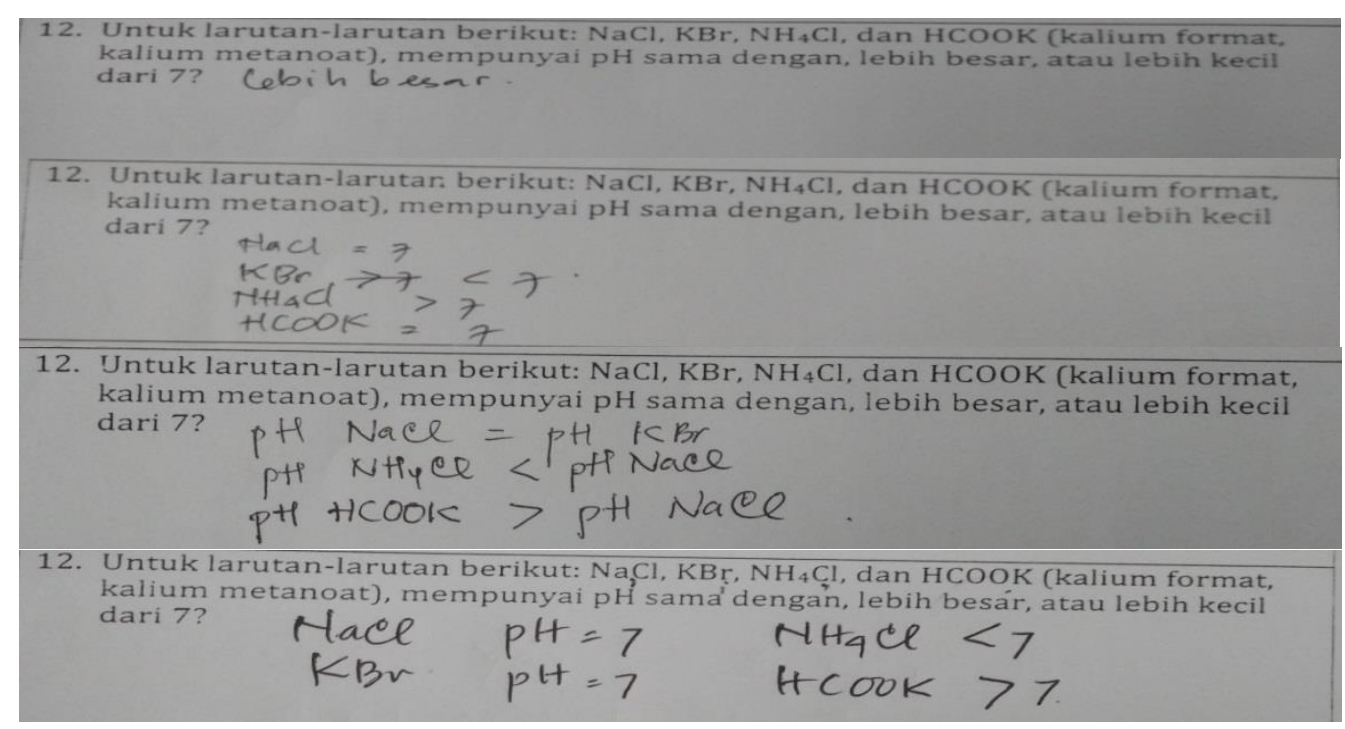

Gambar 1. Cuplikan jawaban responden untuk nilai $\mathrm{pH}$ larutan 
Dari hasil olah data untuk penjelasan nilai $\mathrm{pH}$ atau sifat keasaman larutan garam yang ditanyakan terdistribusi seperti tercantum pada Tabel 2, dan contoh beberapa jawaban oleh responden diperlihatkan pada Gambar 2.

Tabel 2. Pola jawaban responden sebagai penjelasan atau deskripsi $\mathrm{pH}$ larutan $\mathrm{NaCl}, \mathrm{KBr}, \mathrm{NH}_{4} \mathrm{Cl}$, dan $\mathrm{HCOOK}$

Pertanyaan 2: Dari jawaban soal No.1 yang

Anda sampaikan, mengapa $\mathrm{pH}$ masingmasing seperti yang Anda sebutkan? Berikan penjelasan singkat!

\section{Kunci kalimat jawaban benar:}

Larutan dengan $\mathrm{pH} 7$, tidak mengalami hidrolisis

$\mathrm{pH}<7$, menjalani hidrolisis parsial dan menghasilkan ion $\mathrm{H}^{+}$

$\mathrm{pH}>7$, menjalani hidrolisis parsial dan menghasilkan ion $\mathrm{OH}^{-}$
Untuk larutan $\mathrm{NaCl} \& \mathrm{KBr}: \mathrm{NaCl}(\mathrm{s})+$ $\mathrm{H}_{2} \mathrm{O}(\mathrm{l}) \rightarrow \mathrm{Na}^{+}$(aq) $+\mathrm{Cl}^{-}(\mathrm{aq}) ; \mathrm{KBr}(\mathrm{s})+$ $\mathrm{H}_{2} \mathrm{O}(\mathrm{l}) \rightarrow \mathrm{K}^{+}(\mathrm{aq})+\mathrm{Br}^{-}(\mathrm{aq})$

Untuk larutan $\mathrm{NH}_{4} \mathrm{Cl}$ :

$\mathrm{NH}_{4} \mathrm{Cl}(\mathrm{s})+\mathrm{H}_{2} \mathrm{O}(\mathrm{l}) \rightarrow \mathrm{NH}_{4} \mathrm{OH}(\mathrm{aq})+$

$\mathrm{H}^{+}(\mathrm{aq})+\mathrm{Cl}^{-}(\mathrm{aq})$

Untuk larutan $\mathrm{HCOOK}$ :

$\mathrm{HCOOK}(\mathrm{s})+\mathrm{H}_{2} \mathrm{O}(\mathrm{l}) \rightarrow \mathrm{HCOOH}(\mathrm{aq})+$ $\mathrm{OH}^{-}(\mathrm{aq})+\mathrm{K}^{+}(\mathrm{aq})$

\begin{tabular}{lcc}
\hline \multicolumn{1}{c}{ Larutan dan $\mathbf{p H}$ nya } & Ragam penjelasan singkat & Jumlah (49 orang $=\mathbf{1 0 0} \%$ \\
\hline $\mathrm{NaCl}$ dan $\mathrm{KBr}, \mathrm{pH}=7$ & a) $\quad$ Selaras dengan kalimat kunci & 10 orang $(20 \%)$ \\
\cline { 2 - 3 } $\mathrm{NH}_{4} \mathrm{Cl}, \mathrm{pH}<7$ & b) $\mathrm{pH}=7$, karena berasal dari asam & 13 orang $(27 \%)$ \\
$\mathrm{HCOOK}, \mathrm{pH}>7$ & kuat dan basa kuat & \\
& $\mathrm{pH}>7$, karena berasal dari asam & \\
& lemah dan basa kuat \\
& $\mathrm{pH}<7$, karena berasal dari asam \\
& kuat dan basa lemah & \\
\cline { 2 - 3 } & c) Tergantung asam dan basa & 13 orang $(27 \%)$ \\
& pembentuknya atau yang identik & \\
\hline & d) Jawaban lainnya & 13 orang $(27 \%)$ \\
\hline
\end{tabular}

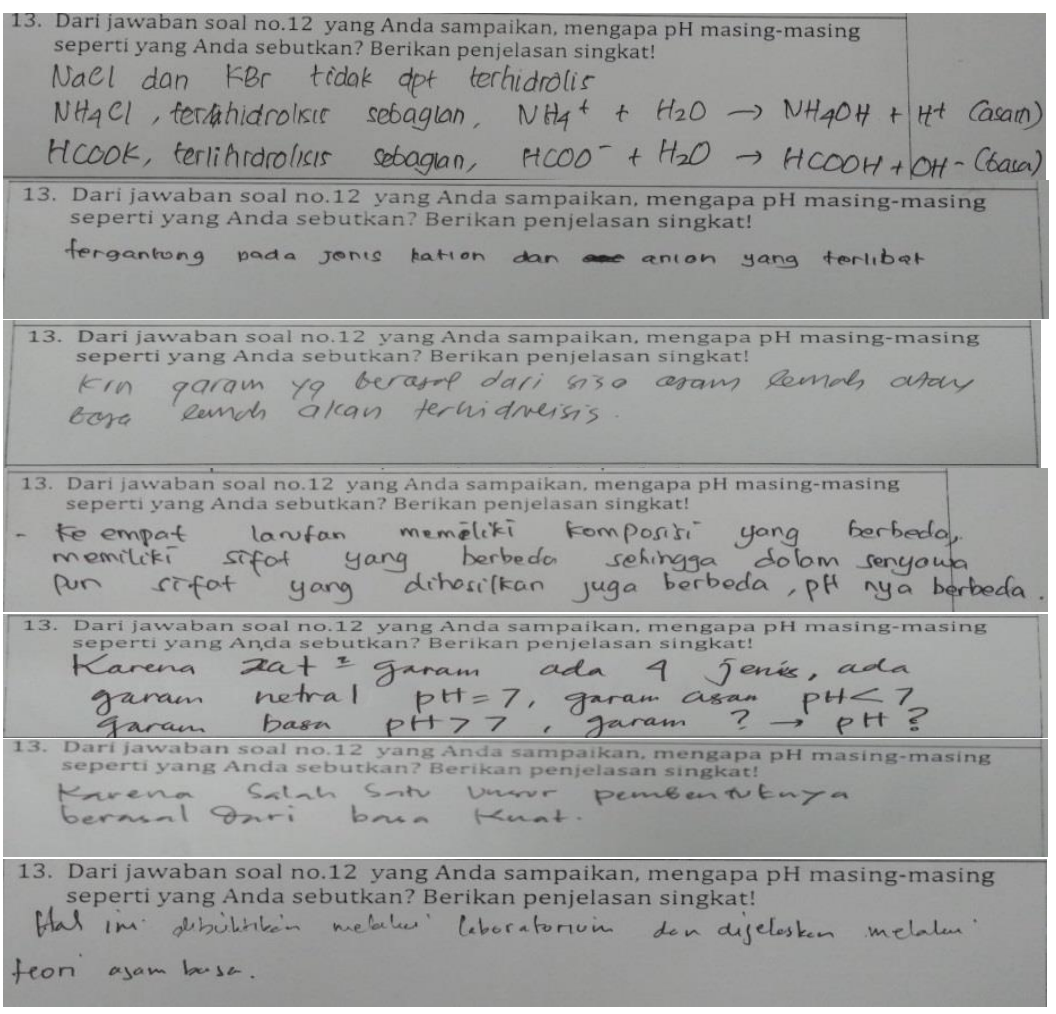

Gambar 2. Cuplikan pola penjelasan nilai $\mathrm{pH}$ larutan garam dari

Berdasarkan respon dalam kuesioner, selanjutnya dilakukan rekonstruksi konsep. Mengapa disebut sebagai rekonstruksi konsep? Pada dasarnya, guru telah memiliki konsep bahwa suatu larutan dengan $\mathrm{pH}=7$ adalah bersifat netral, $\mathrm{pH}<$ bersifat asam, dan $\mathrm{pH}>7$ bersifat. Sebenarnya, untuk melihat atau mengecek 
sifat larutan tidak harus berdasarkan $\mathrm{pH}$ nya, namun yang lebih sederhana melalui perubahan warna kertas lakmus merah dan/atau biru sebelum dan setelah lakmus ini diujikan ke dalam larutan. Rekonstruksi konsep dilakukan dengan langkah-langkah sebagai berikut:

1. Menggali pengetahuan atau konsep awal yang melandasi (prior knowledge), yakni nilai $\mathrm{pH}$ dan hubungannya dengan sifat keasaman larutan. Konsep yang harus dimiliki adalah asam dan basa menurut Teori asam-basa Arrhenius. Di samping itu juga digali konsep larutan; Melalui kegiatan ini diharapkan mampu membuat koneksi konsep ini dengan fenomena ada/tidak adanya perubahan warna kertas lakmus sebelum dan setelah dimasukkan (diujikan) ke dalam larutan garam;

2. Melarutkan garam-garam $\mathrm{NaCl}, \mathrm{KBr}, \mathrm{NH}_{4} \mathrm{Cl}$, dan $\mathrm{HCOOK}$ dengan jumlah yang secukupnya ke dalam air, lalu mengaduknya, dan dilanjutkan dengan mencelupkan kertas lakmus merah dan biru ke dalam setiap larutan; Melalui kegiatan diharapkan mampu memperoleh konsep larutan dan konseksinya dengan sifat keasamannya. Tahap ini melibatkan tingkat berfikir makroskopik;

3. Menstimuli untuk memberikan penjelasan bagaimana bisa memberikan eksplanasi dari langkah-2 dan koneksinya dengan konsep asam dan basa menurut teori asam-basa Arrhenius. Pada tahap ini terjadi proses yang agak panjang namun sudah mulai terjadi konflik dengan konsep yang dimiliki (yang dajukan saat menjawab kuesioner) terutama dari responden yang menjawab KURANG/TIDAK BENAR (ada miskonsepsi). Eksplanasi dilakukan untuk larutan $\mathrm{NaCl}$ dan $\mathrm{NH}_{4} \mathrm{Cl}$; Tahap ini melibatkan tingkat berfikir sub-mikroskopik.

4. Eksplanasi diakhiri dengan menuliskan persamaan reaksi sejalan konsep asam dan basa menurut teori Arrhenius. Dalam hal ini adanya ion $\mathrm{H}^{+}$dan ion $\mathrm{OH}^{-}$dalam larutan dengan jumlah yang ekivalen (untuk larutan $\mathrm{NaCl}$ ) dan adanya ion $\mathrm{H}^{+}$dalam larutan dengan jumlah yang lebih banyak (untuk larutan $\mathrm{NH}_{4} \mathrm{Cl}$ ). Tingkat berfikir dalam tahap ini pada domain simbolik atau representasional;

5. Membuat eksplanasi secara lebih mandiri (berkelompok, 2 orang per kelompok) untuk larutan yang lain $(\mathrm{KBr}$ dan $\mathrm{HCOOK})$ sampai diperoleh persamaan reaksi yang menunjukkan ada/tidak adanya ion $\mathrm{H}^{+}$dan ion $\mathrm{OH}^{-}$yang lebih dominan. Jadi, dimulai dari hasil pengamatan keterlaruta dan perubahan warna kertas lakmus (tingkat berfikir makroskopik), penjelasan mengapa dapat terjadi perubahan warna kertas lakmus dalam larutan itu (tingkat berfikir sub-mikroskopik, dalam hal ini direpresentasikan oleh ion $\mathrm{H}^{+}$dan ion $\mathrm{OH}^{-}$), dan menyusun atau menulis dalam suatu persamaan reaksi (tingkat berfikir simbolik atau representasional);

6. Menyusun suatu inferensi untuk setiap segmen larutan yang mewakili dan mengidentifikasi "partikel penyusunnya" untuk membuat kesimpulan tentang konsep hidrolisis dan karakteristik atau ciri-ciri umum garam yang larutannya bersifat netral, asam, atau basa.

\section{PEMBAHASAN}

Merujuk pada Tabel 1, menunjukkan bahwa menduga nilai $\mathrm{pH}$ suatu larutan garam mayoritas $(87,5 \%$ responden) dengan distribusi $92 \%, 80 \%, 88 \%$, dan $90 \%$ berturut-turut untuk larutan $\mathrm{NaCl}, \mathrm{KBr}, \mathrm{NH}_{4} \mathrm{Cl}$, dan larutan HCOOK dugaannya adalah BENAR. Namun demikian, sebagai seorang guru seharusnya TIDAK ADA seorang gurupun YANG SALAH atau YANG TIDAK DAPAT MENJAWAB dengan benar. Jadi, menduga sifat keasaman yang dimanifestasikan dengan nilai $\mathrm{pH}$ sama dengan, lebih kecil, atau lebih besar 7 sudah harus menjadi kebutuhan dan keniscayaan. Akan tetapi dari survey ini menunjukkan hal yang memprihatinkan, bahkan ada yang TIDAK MAMPU MENJAWAB. Secara kuantitatif, proporsi antara JAWABAN BENAR dengan JAWABAN TIDAK BENAR (SALAH) dapat ditolerir, guru yang menjawab benar jauh lebi banyak dibanding yang menjawab salah.

Meskipun pertanyaan 'Untuk larutan-larutan berikut: $\mathrm{NaCl}$ (natrium klorida), $\mathrm{KBr}$ (kalium bromida), $\mathrm{NH}_{4} \mathrm{Cl}$ (amonium klorida), dan HCOOK (kalium format atau kalium metanoat), mempunyai $p H$ sama dengan, lebih besar, atau lebih kecil dari 7 (tujub)?” mempunyai jawaban yang semi-tertutup, karena pilihan jawaban disediakan, namun setiap memilih harus dilandasi oleh argumen atau alasan yang jelas atau mapan. Hasil olah data untuk memberikan penjelasan atau deskripsi singkat jawaban yang disampaikan pada pertanyaan tersebut, diperoleh informasi dan/atau bukti yang lebih memprihatinkan dibandingkan jawaban terhadap pilihan jawaban yang disediakan. Kondisi memprihantinkan ini dilandasi oleh alasan yang dideskripsikan oleh reponden terhadap jawaban yang disampaikan tentang nilai $\mathrm{pH}$ larutan-larutan $\mathrm{NaCl}, \mathrm{KBr}, \mathrm{NH}_{4} \mathrm{Cl}$, dan larutan HCOOK. Mengapa? Dari jumlah rerata yang menjawab dengan benar untuk nilai masing-masing 
larutan tersebut, ternyata alasan yang disampaikan yang selaras dengan konsep para kimiawan, jumlah jawaban benar jauh lebih sedikit dibanding jawaban BENAR terhadap pertanyaan pertama. Dari jumlah rerata $(87,5 \%)$ atau $\left(92 \%, 80 \%, 88 \%\right.$, dan $90 \%$ berturut-turut untuk larutan $\mathrm{NaCl}, \mathrm{KBr}, \mathrm{NH}_{4} \mathrm{Cl}$, dan larutan HCOOK), guru yang menjawab benar nilai $\mathrm{pH}$ larutan-larutan di atas, HANYA 10 orang $(20 \%$ dari total sampel) yang mendeskripsikan sesuai dengan penjelasan kimiawan. Hal ini menunjukkan bahwa, para guru belum mempunyai penguasaan atau pemahaman konseptual yang konprehensif tentang sifat keasaman larutan garam. Artinya, telah terjadi MISKONSEPSI tentang sifat keasaman larutan ini dari para guru. Dengan memperhatikan pola jawaban sebagaimana tercantum dalam Tabel 2 dan cuplikan jawaban otentiknya seperti pada Gambar 2, terutama pola jawaban kategori (b) dan (c), maka susah untuk dinyatakan sebagai TIDAK TERJADI MISKONSEPSI oleh para guru yang menjadi objek survey ini, jika tidak dinyatakan sebagai LEMAHNYA atau GAGALNYA PEMAHAMAN KONSEP "HIDROLISIS" larutan garam. Jadi, mayoritas guru-guru tersebut TIDAK memahami konsep hidrolisis yang mengakibatnya sifat keasaman larutan garam. di samping itu, berdasarkan bukti-bukti tersebut diduga, konsep $\mathrm{pH}$ dan/atau sifat keasaman suatu larutan elektrolit "hanya" berlaku bagi senyawa yang jelas-jelas ekstrem sebagai ASAM atau BASA. Artinya, larutan yang bersifat netral $(\mathrm{pH}=7)$, larutan bersifat asam $(\mathrm{pH}<7)$, dan suatu larutan bersifat basa $(\mathrm{pH}>7)$ dimaknai hanya untuk senyawa golongan asam, basa, atau netral. Dugaan ini didukung oleh argumen yang disampaikan, yakni:

(1) larutan $\mathrm{NaCl}$ atau $\mathrm{KBr}$ mempunyai $\mathrm{pH}=7$, karena berasal dari asam kuat dan basa kuat,

(2) larutan $\mathrm{NH}_{4} \mathrm{Cl} p \mathrm{H}$ nya $>$ 7, larutan karena berasal dari asam lemah dan basa kuat,

(3) larutan HCOOK mempunyai $p H<7$, karena berasal dari asam kuat dan basa lemah, dan

(4) pernyataan "tergantung asam dan basa pembentuknya".

Tampak bahwa dengan deskripsi jawaban seperti di atas, hanya konsep asam dan basa yang sangat melakat pada alam pikir (benak) guru. Teori asam-basa yang selama ini sudah "dimiliki" kurang atau tidak melekat dalam alam pikirnya. Larutan dengan $\mathrm{pH}<7$ yang menggambarkan bersifat asam "HANYA" dimiliki oleh senyawa-senyawa asam. Demikian juga untuk yang bersifat basa. Berbagai teori asam-basa (Arrhenius, Bronsted-Lowrey, apalagi Lewis) yang sudah pernah diperoleh "TIDAK MENJADI MILIKNYA". Tentunya kondisi yang demikian akan "berdampak fatal" jika belajar konsep-konsep asam atau basa untuk level konsep yang lebih tinggi. Misalnya mekanisme reaksi dalam reaksi-reaksi berkatalisis yang lebih didominasi teori asam-basa Lewis atau Bronsted-Lowrey. Jadi, telah terjadi miskonsepsi tentang konsep hidrolisis tidak bisa ditolak.

Mengingat guru yang menjadi objek survey mempunyai latar belakang pengalaman mengajar yang relatif cukup lama, meski juga tidak sedikit yang tergolong sebagai "guru pemula", maka terjadi miskonsepsi konsep hidrolisis menjadi permasalahan tersendiri. Tampaknya bahasa simbol menjadi lebih mendominasi penguasaan konsep di alam pikir para guru yang menjadi objek survey ini. Karenanya, perlu penataan kembali atau "penanaman kembali" konsep hidrolisis dengan lebih menekankan sifat keasaman yang dilandasi teori asam-basa (sebagai prior-knowledge) untuk dapat menjelaskan sifat keasaman larutan garam secara komprehensif dan benar. Penataan kembali atau penanaman kembali konsep inilah yang disebut sebagai rekonstruksi konsep atau rekonstruksi konseptual (conceptual reconstruction) (Sam et al., 2015 \& Zuriff, 1986).

Dalam rekonstruksi konsep, kemampuan untuk mengidentifikasi prior knowledge dan mengkoneksinya dengan konsep yang akan dipelajari sangat menentukan. Dengan rekonstruksi konsep melalui tahapan sebagaimana dideskripsikan di bagian sebelumnya, maka prior knowledge untuk konsep hidrolisis (sifat keasaman larutan garam) adalah konsep asam dan basa, khususnya menurut teori Arrhenius, meski juga dapat digunakan teori Bronsted-Lowrey.

Eksplorasi prior knowledge, khususnya definisi asam dan basa menurut teori Arrhenius, (saat implementasi rekonstruksi konsep) tidak ada masalah yang berarti dari para guru. Namun, setelah dieksplorasi, mengapa larutan natrium klorida bersifat netral, larutan amonium klorida bersifat asam, dan larutan kalium format bersifat basa kembali menjadi masalah. Maknanya, guru tidak mampu mengkoneksi prior-knowledge nya untuk mengeksplanasi sifat keasaman larutan-larutan tersebut. Setelah dieksplorasi terhadap apa yang diamati saat mempreparasi larutan-larutan tersebut, baru mulai "menyadari" bahwa setiap larutan tersebut hanya mengandung garam tersebut dan air sebagai pelarut. Dari fakta inilah, tercipta konflik, dan selanjutnya diarahkan ke konsep asam dan basa menurut teori Arrhenius, dan mulailah mereka berfikir 
bahwa untuk larutan amonium klorida (senyawa yang dilarutkan dalam air) secara konsep harus menghasilkan ion hidrogen (ion $\mathrm{H}^{+}$). Dengan bantuan pemahaman dan eksplanasi, akhirnya konsep hidrolisis dapat dipahami. Demikian juga untuk larutan kalium format dan larutan natrium klorida. Melalui proses rekonstruksi inilah, guru mulai menyadari terjadinya miskonsepsi pada dirinya. Hal ini sejalan dengan respon mereka yang dijaring melalui kuesioner.

Bagaimana respon para guru terhadap rekonstruksi konsep dan menyadari telah terjadi miskonsepsi untuk konsep hidrolisis? Rangkuman analisis angket rekonstruksi miskonsepsi untuk konsep keasaman larutan garam atau yang lebih familiar dengan Konsep Hidrolisis diperoleh hasil sebagai berikut:

1. Sebanyak $98 \%$ reponden menyatakan KEYAKINANNYA bahwa mereka menerima secara utuh apa yang telah disampaikan/ dideskripsikan/ dijelaskan dalam merekonstruksi konsep hidrolisis (sifat keasaman larutan garam), sedang yang menyatakan biasa saja atau ragu hanya $2 \%$, dan tidak ada seorangpun yang menyatakan TIDAK YAKIN

2. Tentang makna "Rekonstruksi konsep-konsep fundamental kimia yang disampaikan menjadikan saya lebih memahami dan memaknai dari apa yang telah saya miliki (sebelumnya), 95\% responden menyatakan yakin/ya, 5\% responden menyatakan biasa saja/ ragu, dan tidak ada yang menyatakan tidak yakin.

3. Jadi, hampir tidak ada ( $98 \%$ responden) yang menyatakan tidak bermanfaat atau tidak menambah pemahaman atau tidak terjadi rekonstruksi.

4. Setelah memperoleh rekonstruksi konsep ini, menyadari bahwa Pengetahuan/ Ilmu Kimia merupakan ilmu yang sistematik, menarik, mudah untuk dipelajari dan dibelajarkan. Sebanyak 95\% menyatakan ya/yakin, dan yang menyatakan biasa saja/ ragu, dan tidak yakin masing-masing $2,5 \%$.

5. Setelah memperoleh kegiatan rekonstruksi konsep ini, peserta (para guru) sadar bahwa ADA MISKONSEPSI pada diri saya.

6. Rekonstruksi konsep hidrolisis ini sangat bermanfaat untuk memperbaiki pembelajaran di kelasnya, sebanyak $92,5 \%$ menyatakan ya/yakin, dan yang menyatakan biasa saja/ ragu dan tidak yakin masingmasing 2,5\%, dan 2,5\% responden tidak menjawab (abstain).

7. Pengetahuan prasyarat (prior knowledge) atau konsep awal sangat menentukan keberhasilan peserta didik untuk memahami konsep yang (akan) dipelajari, diyakini 100\% dari para peserta Rekonstruksi Salah-Konsep ini.

8. Pembelajaran kimia sudah saatnya dan sewajarnya diawali dengan mengeksplorasi fakta melalui fenomena-fenomena dengan melibatkan ragam sumber belajar menjadi suatu keharusan dan keniscayaan, seluruh responden menyatakan ya/ setuju.

9. Pembelajaran kimia yang diawali dengan simbol (bahasa simbol) sebaiknya ditinggalkan, reponden yang menyatakan ya/yakin sebanyak $80 \%$, biasa saja/ ragu sebanyak $18 \%$, dan tidak yakin sebanyak $2 \%$.

Mengingat konsep-konsep di ilmu kimia didominasi konsep abstrak, maka pada konsep-konsep yang seperti ini lebih tepat menggunakan cara berfikir khas yang berbeda dengan nalar ilmiah untuk memperoleh penjelasan yang logis (Turanyi, 2013; Tan et al., 2005). Herron dan Wiseman (dalam Effendy, 2002) menyarankan bahwa untuk memahami konsep abstrak siswa perlu membiasakan diri menggunakan kemampuan berfikir formal atau abstrak. Karakteristik konsep dalam ilmu kimia selain abstrak (dan knkrit) juga terdapat konsep terdefinisi memicu terjadinya pemahaman yang rancu sehingga menyebabkan pemahaman konsep peserta didik menjadi tidak tepat (Effendy, 2010). Oleh karena itu memahami karakteristik konsep dalam ilmu kimia akan membantu pemahaman yang benar terhadap konsep tersebut.

\section{KESIMPULAN}

Identifikasi miskonsepsi terhadap guru, mahasiswa, dan siswa merupakan hal yang penting untuk dilakukan. Miskonsepsi sangat sulit diubah karena kecenderungannya yang tertancap kuat sebagai konsep yang benar dalam pola pikir (alam pikir) mereka (siswa, mahasiswa, dan/atau guru). Miskonsepsi pada guru dan mahasiswa akan lebih berdampak fatal, sebab ditangan kedua pelaku ini diharapak terjadi agent of change dan transfre of knowledge secara mendasar dan berkelanjutan. Miskonsepsi terjadi pada guru, untuk konsep apa saja, tidak sebatas konsep hidrolisis akan menjadi rentetan kesalahan konsep yang 
berkepanjangan dan akan menjadi penghambat pemahaman konsep lanjutannya secara benar, tepat, dan komprehensif. Rekonstruksi konsep untuk guru dan/atau mahasiswa lebih cocok atau sesuai untuk memperbaiki miskonsepsi yang terjadi. Kesadaran telah terjadi miskonsepsi pada dirinya menjadi bekal yang baik dan menggembirakan untuk memperbaiki miskonsepsi yang telah terjadi meski sudah terjadi dalam kurun aktu yang sangat lama. Ilmu Kimia yang bersifat sistematik, hierarkial, dan saling terkonseksi antar konsep, maka penguasaan pengetahuan prasyarat (prior-knowledge) dan koneksi dengan konsep lajutannya mutlak diperlukan. Penguasaan prior-knowledge dan koneksinya dengan konsep lanjutannya menjadi penentu proses pembelajaran yang benar agar terjadi transfer of knowledge kepada peserta didik.

\section{DAFTAR RUJUKAN}

Barke, H. D., Al Hazari, Yitbarek, S. (2009). Misconceptions in Chemistry. Verlag Berlin Heidelberg: Springer Effendy (2002). Upaya Mengatasi Kesalahan Konsep dalam Pembelajaran Kimia dengan Menggunakan Strategi Konlik Kognitif. Jurnal Media Komunikasi Kimia. No. 2 th 6.

Effendy (2010). A-Level Chemistry for senior High School Students (volume 1A). Malang: Bayumedia Publishing.

Enger, S.K. \& Yager, R.E. (2009). Assessing Student Understanding in Science: A Standard-Based K-12 Handbook. California: Corwin A SAGE Company.

Gabel, D. (1999). Improving Teaching and Learning through Chemistry Education Research: A Look to the Future. J. Chem. Educ., 76 (4), 548-553.

Johnstone, A.H. (1991). Intl. J. Chem. Educ. 36, 7 - 10

Mahaffy, P. (2006). Moving chemistry education into 3D: A Tetrahedral metaphor for understanding chemistry. J. Chem. Educ., 83 (1), 49-55.

Nakhleh, M. B. (1992). Why Some Students Don't Learn Chemistry. Journal of Chemical Education. Vol. 69, No. 3, 191-196

Sam, A., Niebert, K., Hanson, R., \& Twumasi, A.K. (2015). The model of educational reconstruction: scientists' and students' conceptual balances to improve teaching of coordination chemistry in higher education. International Joumal of Academic Research and Reflection, 3 (7), 67-77

Sirhan, G. (2007). Learning Difficulties in Chemistry: An Overview. Journal Of Turkish Science Education. Vol. 4, No. 2, 2-20.

Zuriff, G.E. (1986). Precis of behaviorism: a conceptual reconstruction. Behavioral and Brain Sciences, 9, 687724 